\title{
Epigenetic alterations in neuroendocrine tumors: methylation of RAS-association domain family 1, isoform $A$ and p16 genes are associated with metastasis
}

\author{
Lixia Liu ${ }^{1}$, Russell R Broaddus ${ }^{1}$, James C Yao ${ }^{2}$, SuSu Xie ${ }^{1}$, Jill A White ${ }^{1}$, Tsung-Teh Wu ${ }^{1}$, \\ Stanley R Hamilton ${ }^{1}$ and Asif Rashid ${ }^{1}$ \\ ${ }^{1}$ Department of Pathology, The University of Texas MD Anderson Cancer Center, Houston, TX, USA and \\ ${ }^{2}$ Department of Gastrointestinal Oncology, The University of Texas MD Anderson Cancer Center, Houston, \\ $T X, U S A$
}

\begin{abstract}
Well-differentiated neuroendocrine tumors including pancreatic endocrine tumors and carcinoid tumors are uncommon neoplasms that have site-specific differences in clinicopathological features, clinical course and genetic alterations. The epigenetic alterations in these tumors are not well characterized. We therefore compared methylation of the RAS-association domain family 1, isoform A (RASSF1A), p14, p16 and $O^{6}$-methylguanine methyltransferase genes in neuroendocrine tumors from 47 patients including 16 pancreatic, 15 nonileal and 16 ileal neuroendocrine tumors. Methylation of the RASSF1A gene was present in $57 \%$ of tumors, $p 14$ in $49 \%, p 16$ in $26 \%$ and $O^{6}$-methyl-guanine methyltransferase in $13 \%$ of tumors. Ileal neuroendocrine tumors lacked methylation of $O^{6}$-methyl-guanine methyltransferase gene $(P=0.04)$. RASSF1A methylation was associated with histopathologic type of tumors $(P=0.03)$ and lymph node metastasis $(P=0.004)$, and p16 methylation with older patient age $(P=0.002)$ and liver metastasis $(P=0.04)$. Two or more genes were methylated in $53 \%$ of tumors, one gene was methylated in $30 \%$ of tumors, and all four genes were unmethylated in $17 \%$ of tumors. Methylation of one or more gene was associated with older age of patients $(P=0.01)$, and methylation of two or more genes was associated with liver metastasis $(P=0.044)$. Our study shows that in neuroendocrine tumors epigenetic alterations vary by tumor subsite and clinicopathologic features, including age of onset, histopatholoic type and metastasis status.
\end{abstract}

Modern Pathology (2005) 18, 1632-1640. doi:10.1038/modpathol.3800490; published online 7 October 2005

Keywords: methylation; pancreatic endocrine tumors; carcinoid tumors

Well-differentiated neuroendocrine tumors including pancreatic endocrine tumors and carcinoid tumors of the lung and gastrointestinal tract are uncommon, ${ }^{1,2}$ with an age-adjusted annual incidence of 2.5-4.5 per $1000000^{3,4}$ These indolent malignancies have site-specific differences among well-differentiated neuroendocrine tumors from lung, gastrointestinal tract, and pancreas including clinicopathological features, behavior and genetic alterations.

The molecular mechanisms of neuroendocrine tumorigenesis are poorly understood but have been the focus of many recent reports. ${ }^{5-11}$ We have

Correspondence: Dr A Rashid, MD, PhD, Department of Pathology, Box 85, The University of Texas MD Anderson Cancer Center, 1515 Holcombe Boulevard, Houston, TX 77030, USA.

E-mail: arashid@mdacc.tmc.edu

Received 16 June 2005; revised 27 July 2005; accepted 2 August 2005; published online 7 October 2005 previously shown methylation of p14 (ARF), p16 (INK4a) and $O^{6}$-methyl-guanine methyltransferase (MGMT) genes in well-differentiated neuroendocrine tumors from pancreas and gastrointestinal tract. $^{11}$

A chromosome 9p21 locus encodes two cell cycle inhibitors, $p 16$ and $p 14$, that are transcribed from two separate promoters and first exons $(1 \alpha$ and $1 \beta$, respectively) joined through the same splice acceptor site to exon 2 coding sequences but in different reading frames. ${ }^{12,13}$ p16 inhibition of cyclin-dependent kinase 4 (CDK4) causes retinoblastoma protein to stay in its active form and arrest the cell cycle at G1-S transition. ${ }^{14,15}$ p14 also inhibits the cell cycle by blocking MDM2 inhibition of p53 activity. ${ }^{16}$ Inactivation of the $p 16$ and $p 14$ genes has been reported for a variety of tumors. ${ }^{15,17-19}$ Both $p 16$ and p14 can be inactivated through gene mutation, heterozygous or homozygous deletion, and methylation of the CpG island in the promoter region. In 
pancreatic and gastrointestinal well-differentiated neuroendocrine tumors, methylation of the promoter region is the major mechanism for inactivation of these two tumor suppressor genes. ${ }^{8}$

$M G M T$ is a DNA repair gene that is responsible for removal of mutagenic adducts from the $\mathrm{O}^{6}$ position of guanine. ${ }^{20}$ In cells lacking MGMT activity, $\mathrm{O}^{6}$ alkyl-guanine mispairs with thymine during DNA replication and results in guanine-cytosine transition mutation. Methylation of $\mathrm{CpG}$ islands in the promoter regions of the MGMT gene can cause loss of transcription of the gene, and promoter methylation has been reported in many tumor types, ${ }^{20}$ including pancreatic well-differentiated neuroendocrine tumors. ${ }^{7}$

RAS-association domain family 1 has seven different isoforms that are produced by alternative splicing and transcription from two different promoters with $\mathrm{CpG}$ islands. ${ }^{21}$ RAS-association domain family 1 , isoform $\mathrm{A}(R A S S F 1 A)$ gene is a tumor suppressor gene in the RAS pathway that can regulate proliferation, induce apoptosis, and bind to and stabilize microtubules. RASSF1A gene is frequently methylated in a variety of tumors, ${ }^{21}$ including pancreatic, pulmonary and gastrointestinal well-differentiated neuroendocrine tumors. ${ }^{7,22-24}$

In the present study, we studied well-differentiated neuroendocrine tumors from the pancreas, lung and gastrointestinal tract for methylation of RASSF1A, p14, p16 and MGMT genes, and associated the epigenetic alterations with clinicopathologic features including metastasis status. We found associations with tumor site, histopatholoic type, patient age and metastasis that have implications for the pathogenesis of the tumors and clinical characteristics.

\section{Materials and methods}

\section{Characteristics of Specimens and Patients}

Frozen tumor and non-neoplastic tissue were obtained from surgical specimens of patients undergoing resections for well-differentiated neuroendocrine tumors in the frozen section laboratory of the Department of Pathology, MD Anderson Cancer Center. The MD Anderson Cancer Center Surveillance Committee (institutional review board) approved this study. The patient records and histopathological findings were reviewed. The tumors were classified as benign well-differentiated neuroendocrine tumors, well-differentiated neuroendocrine tumors of uncertain malignant potential, and well-differentiated neuroendocrine carcinomas using established criteria. ${ }^{25}$ There were three benign well-differentiated neuroendocrine tumors, nine well-differentiated neuroendocrine tumors of uncertain malignant potential, and 35 well-differentiated neuroendocrine carcinomas (Figure 1). Of these well-differentiated neuroendocrine tumors, 16 were from pancreas (pancreatic endocrine tumors), and 31 were from lung and gastrointestinal tract (carcinoid tumors). Of the tumors, 16 were in the ileum. The nonileal tumors included five pulmonary, three gastric, two duodenal, one appendiceal, three cecal and one rectal tumor. The functional status of tumors was ascertained by serum measurements of hormones and/or clinical syndrome due to hormonal hypersecretion. There was one gastrinoma and one insulinoma. Two patients with pancreatic neuroendocrine tumors had multiple endocrine neoplasia type 1 (MEN1), and two patients with gastric well-differentiated neuroendocrine tumors had chronic atrophic gastritis of the body and fundus associated with Pernicious anemia.

\section{DNA Extraction}

DNA from both tumor and non-neoplastic tissue was extracted from microdissected fresh-frozen specimens using a commercial kit (Qiagen DNA extraction kit, Qiagen Inc., Valencia, CA, USA), after a hematoxylin- and eosin-stained slide from a frozen block was reviewed. The tumor cell cellularity was at least $90 \%$ in all samples examined. The nonneoplastic tissue was from the pancreatic or lung parenchyma, or normal mucosa from the primary site of tumor and had a minor component of neuroendocrine cells or islets of Langerhans. The tumor tissue was obtained from the liver metastases in one patient with pancreatic and five patients with ileal well-differentiated neuroendocrine carcinomas and the non-neoplastic tissue from the primary site was unavailable from these patients (Figure 1).

\section{Methylation of RASSF1A, p14, p16, and MGMT Genes}

Methylation of the RASSF1A, p14, p16, and MGMT genes was evaluated by bisulfite treatment of DNA followed by methylation-specific polymerase chain reaction (MSP), as previously described. ${ }^{6,20,26-28}$ In brief, $2 \mu \mathrm{g}$ of microdissected genomic DNA was denatured with $2 \mathrm{M} \mathrm{NaOH}$ at $37^{\circ} \mathrm{C}$ for $10 \mathrm{~min}$, followed by incubation with $3 \mathrm{M}$ sodium bisulfite, $\mathrm{pH}$ 5.0 , at $50^{\circ} \mathrm{C}$ for $16 \mathrm{~h}$ in darkness. After treatment, DNA was purified using the DNA Cleanup Kit (Promega Corporation, Madison, WI, USA) as recommended by the manufacturer, incubated with $3 \mathrm{M} \mathrm{NaOH}$ at room temperature for $5 \mathrm{~min}$, precipitated with $10 \mathrm{M}$ ammonium acetate and $100 \%$ ethanol, washed with $70 \%$ ethanol, and finally resuspended in $20 \mu \mathrm{l}$ of distilled water. RASSAF1 gene methylation was determined by PCR amplification of unmethylated alleles by using primer pair: 5'-TTTGGTTGGAGTGTGTT AATGTG- $3^{\prime}$ and 5'-CAAACCCCACAAACTAAA AACAA- $3^{\prime}$, and methylated alleles by using primer pair: $5^{\prime}$-GTGTTAACGCGTTGCGTATC- ${ }^{\prime}$ and $5^{\prime}$-AAC CCCGCGAACTAAAAACGA- $3^{\prime} .^{28}$ PCR was carried 


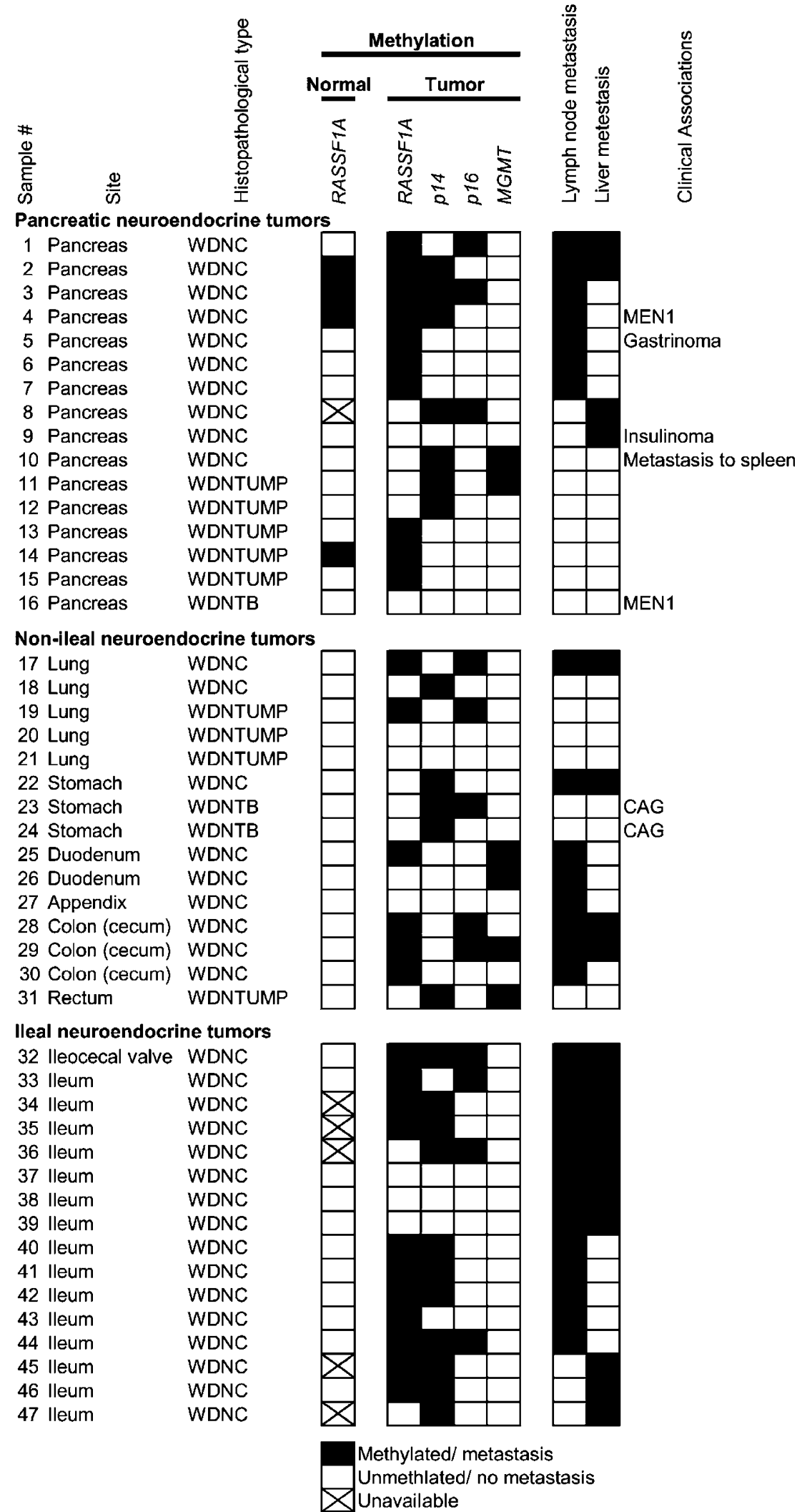

Abbreviations: chronic atrophic gastritis, CAG; well-differentiated neuroendocrine carcinoma, WDNC; well-differentiated neuroendocrine tumor, benign, WDNTB;

well-differentiated neuroendocrine tumor, uncertain malignant potential, WDNTUMP.

Figure 1 Methylation status of RASSF1A, p14, p16 and MGMT genes in pancreatic, nonileal and ileal neuroendocrine tumors, histopatholoic type, and lymph node and liver metastasis status. 
out using the following conditions: denaturation at $95^{\circ} \mathrm{C}$ for $15 \mathrm{~min}, 35$ cycles $\left(95^{\circ} \mathrm{C}\right.$ for $30 \mathrm{~s}, 60^{\circ} \mathrm{C}$ for $30 \mathrm{~s}, 72^{\circ} \mathrm{C}$ for $45 \mathrm{~s}$ ) and extension at $72^{\circ} \mathrm{C}$ for $10 \mathrm{~min}$. The primers and PCR conditions for the $p 14, p 16$ and MGMT genes are as previously reported..$^{20,26,27}$ The colon cancer cell line RKO (American Type Culture Collection, Manasas, VA, USA) and water were used as positive and negative controls, respectively. PCR products from methylated and unmethylated reactions were electrophoresed on $6 \%$ acrylamide gels and visualized by ethidium bromide staining (examples in Figure 2). Samples with low level of methylation (less than 5\% methylated alleles compared to unmethylated alleles were designated as unmethylated based on previous studies. ${ }^{6}$ The methylation status of $p 14, p 16$ and MGMT genes of 12 of the tumors has been reported previously. ${ }^{6}$
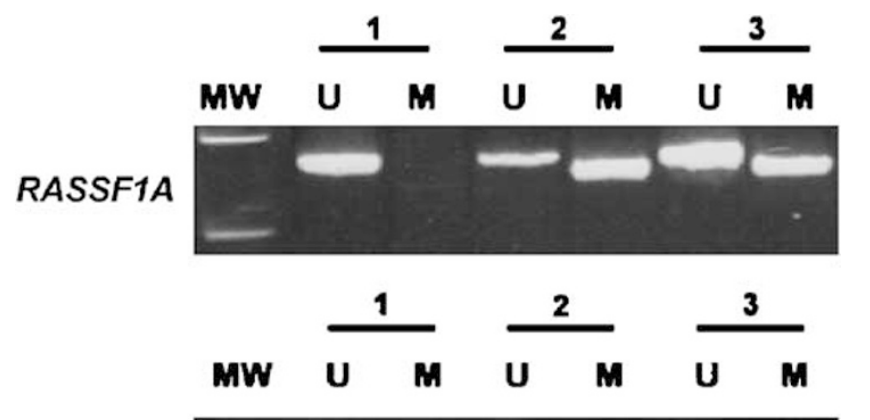

p14
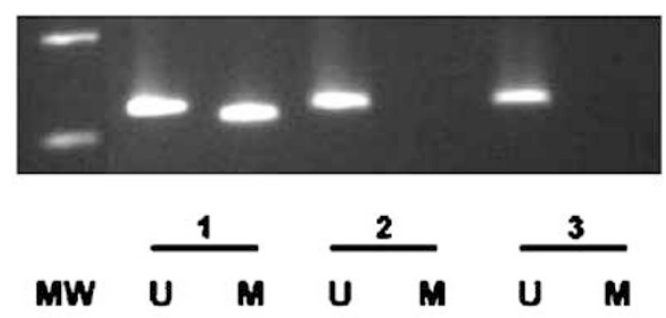

p16
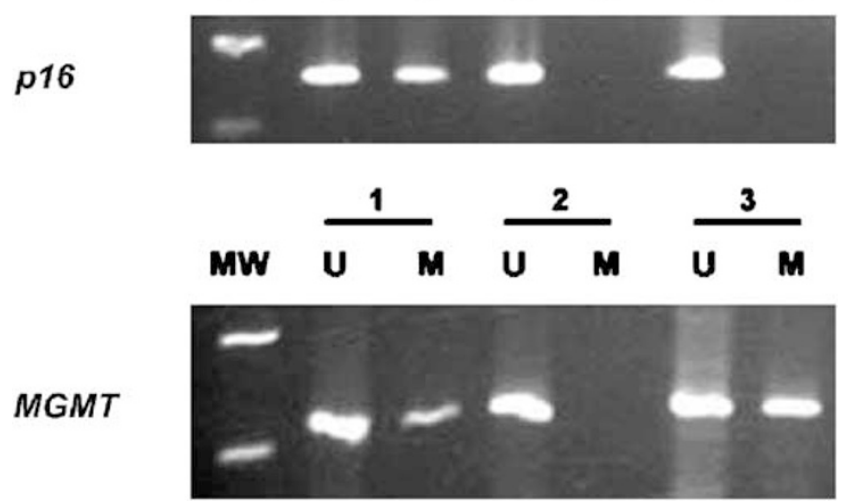

Figure 2 Methylation-specific PCR for RASSF1A, p16, p14 and $M G M T$ genes using unmethylated (U) and methylated (M) primers in three representative samples. Sample numbers and molecular weight (MW) is on the top of the lanes. Sample 1 is unmethylated and samples 2 and 3 are methylated for RASSF1A gene, samples 1 is methylated and samples 2 and 3 are unmethylated for $p 14$, sample 1 is methylated and samples 2 and 3 are unmethylated for p16; and samples 1 and 3 are methylated and samples 2 is unmethylated for MGMT.

\section{Statistical Analysis}

All statistical analysis was performed using SPSS (SPSS Inc., Chicago, IL, USA). Comparisons of categorical variables were made using $\chi^{2}$ and Fisher's exact test. Continuous data, including age at diagnosis and tumor size, were evaluated by Student's T-test and one-way ANOVA.

\section{Results}

\section{Clinicopathologic Features}

The clinicopathological features of the 16 patients with pancreatic well-differentiated neuroendocrine tumors, 15 with nonileal well-differentiated neuroendocrine tumors and 16 with ileal welldifferentiated neuroendocrine tumors have been previously reported. ${ }^{11}$ Liver metastasis was present in $69 \%$ of patients with ileal neuroendocrine tumors compared to $27 \%$ with nonileal neuroendocrine tumors and $25 \%$ with pancreatic neuroendocrine tumors $(P=0.02)$. Age, gender, size of tumor, and vital status were not statistically different among the three groups.

\section{Methylation of RASSF1A, p14, p16, and MGMT Genes}

Methylation of the RASSF1A gene was present in non-neoplastic pancreatic parenchyma of $26 \%$ (4/15) patients with pancreatic neuroendocrine tumors, but was unmethylated in non-neoplastic lung parenchyma from five patients, and three gastric, two duodenal, eight ileal and four colorectal (including one from the patient with appendiceal neuroendocrine tumor) non-neoplastic mucosal samples from patients with nonileal and ileal neuroendocrine tumors. Methylation of $p 14, p 16$ and MGMT genes is infrequent in non-neoplastic pancreas or gastrointestinal mucosa, as reported in our previous study. ${ }^{6}$

Methylation of the RASSF1A gene was present in $57 \%(27 / 47)$ of tumors, of the p14 gene in $49 \%(23 /$ $47)$, of the $p 16$ gene in $26 \%(12 / 47)$, and of the MGMT gene in $13 \%(6 / 47)$ of tumors (Figure 1 and Table 1$).$ Pancreatic, nonileal and ileal neuroendocrine tumors had methylation of RASSF1A gene in 63, 40 and $69 \%$ of tumors, respectively (not significant), p14 gene in 44,33 and $69 \%$ (not significant), p16 gene in 19, 33 and $25 \%$ (not significant), and MGMT gene in 13, 27 and $0 \%(P=0.04)$.

\section{Epigenetic Alterations and Clinicopathologic Features}

The mean age of patients whose non-neoplastic pancreatic parenchyma had RASSF1A gene methylation was $54.2 \pm 15.4$ years, compared to $55.8 \pm 17.2$ years for those whose non-neoplastic pancreatic parenchyma was unmethylated (not significant), and $58.7 \pm 13.1$ years for those whose non-neoplastic 
Table 1 Frequency of methylation of RASSAF1A, p14, p16 and MGMT genes in pancreatic, nonileal and ileal neuroendocrine tumors

\begin{tabular}{|c|c|c|c|c|}
\hline Methylation & $\begin{array}{c}\text { Pancreatic } \\
\text { neuroendocrine } \\
\text { tumors }(\mathrm{n}=16) \%(\text { no.) }\end{array}$ & $\begin{array}{c}\text { Nonileal } \\
\text { neuroendocrine } \\
\text { tumors }(\mathrm{n}=15) \%(\text { no.) }\end{array}$ & $\begin{array}{l}\text { Ileal neuroendocrine } \\
\text { tumors }(\mathrm{n}=16) \% \text { (no.) }\end{array}$ & $\mathrm{P}$-value \\
\hline$R A S S F 1 A$ & $63(10)$ & $40(6)$ & $69(11)$ & $\mathrm{NS}^{\mathrm{b}}$ \\
\hline p14 & $44(7)$ & 33 (5) & 69 (11) & NS \\
\hline p16 & $19(3)$ & $33(5)$ & $25(4)$ & NS \\
\hline$M G M T$ & $13(2)$ & $27(4)$ & $0(0)$ & 0.04 \\
\hline
\end{tabular}

${ }^{\mathrm{a} C o m p a r i s o n}$ among all three groups.

${ }^{\mathrm{b}} \mathrm{NS}$, not significant.

pancreatic or lung parenchyma, or mucosa was unmethylated (not significant).

Methylation status of the RASSF1A, p14, p16 and $M G M T$ genes and clinicopathologic features are compared in Table 2. CpG island methylation at RASSF1A was associated with histopathologic type of tumor and lymph node metastasis, and p16 methylation was associated with patient age and liver metastasis status. RASSF1A methylation was present in $66 \%$ of well-differentiated neuroendocrine carcinomas, $56 \%$ of well-differentiated neuroendocrine tumors of uncertain malignant potential but in $0 \%$ of benign well-differentiated neuroendocrine tumors $(P=0.03)$. Lymph node metastasis was present in $78 \%$ of patients whose tumors had RASSF1A methylation compared to $35 \%$ in patients whose tumors were unmethylated at $p 16(P=0.004)$. The mean age of patients whose tumors had $p 16$ methylation was $68.3 \pm 8.7$ years, compared to $54.8 \pm 13.0$ years for those without $p 16$ methylation $(P=0.002)$. Liver metastasis was present in $67 \%$ of patients whose tumors had p16 methylation compared to $31 \%$ in patients whose tumors were unmethylated at $p 16(P=0.04)$.

The number of methylated genes and clinicopathologic features are compared in Table 3. Two or more genes were methylated in $53 \%(25 / 47)$ of tumors, one gene was methylated in $30 \%(14 / 47)$ of tumors, and all four genes were unmethylated in $17 \%(8 / 47)$ of tumors (Figure 2). The mean age of patients whose tumors had methylation of two or more gene was $61.4 \pm 12.7$ years, compared to $60.6 \pm 10.7$ years for those with methylation of one gene, and $45.7 \pm 14.9$ years for those with no methylated gene $(P=0.01)$. Liver metastasis was present in $52 \%$ of patients whose tumors had methylation of two or more genes, compared to $14 \%$ in patients whose tumors had methylation of one gene and $50 \%$ in those patients who had no methylation of any of the genes $(P=0.044)$.

Some of these associations were also present when tumor subsites were considered (Tables 2 and 3). Patients whose pancreatic well-differentiated neuroendocrine tumors were methylated at RASSF1A gene had more frequent lymph node metastasis $(P=0.002)$, and whose tumors had methylation of one or more genes were older compared to those whose tumors were unmethylated at all four genes $(P=0.01)$. Patients whose nonileal well-differentiated neuroendocrine tumors were methylated at $R A S S F 1 A$ gene had more frequent lymph node metastasis $(P=0.049)$, and whose tumors had $p 16$ gene methylation had more frequent liver metastasis $(P=0.04)$. The patients whose ileal well-differentiated neuroendocrine tumors had $p 16$ methylation were older compared to those without $p 16$ methylation $(P=0.03)$.

\section{Discussion}

In the current study, we found RASSF1A gene to be frequently methylated in all three sites of welldifferentiated neuroendocrine tumors: $63 \%$ in pancreatic tumors, $40 \%$ in nonileal tumors, and $69 \%$ in ileal tumors. It was the most frequently methylated gene in our study. Similarly, high frequency of RASSF1A gene methylation has been reported in pancreatic and gastrointestinal well-differentiated neuroendocrine tumors, ${ }^{7,23,24,29}$ but a slightly lower frequency in pulmonary well-differentiated neuroendocrine tumors. ${ }^{22}$ The RAS-association domain family 1 gene has several isoforms including RASSF1A and RASSF1C that are transcribed from two different CpG island promoters. ${ }^{29-31}$ The hypermethylation of $R A S S F 1 A$ promoter is frequent in many human cancers, and there is an inverse correlation between $R A S S F 1 A$ silencing by methylation and $K-R A S$ activation. ${ }^{21,29-31}$ Previous studies have shown that well-differentiated neuroendocrine tumors lack $K-R A S$ or $B R A F$ mutations, ${ }^{11,32,33}$ but have methylation of $R A S S F 1 A$ gene in pancreatic, pulmonary and gastrointestinal well-differentiated neuroendocrine tumors. ${ }^{7,22-24}$ This suggests that RAS pathway is involved in well-differentiated neuroendocrine tumors mostly by gene silencing of RASSF1A gene by methylation.

In our study, methylation of $p 16$ was found in $19 \%$ of pancreatic tumors, $33 \%$ of nonileal tumors and $25 \%$ of ileal tumors as we reported previously. ${ }^{6}$ Similarly, methylation of $p 16$ gene was reported in more than $50 \%$ of gastrinomas and nonfunctional pancreatic well-differentiated neuroendocrine in previous studies $^{34}$ and in $40 \%$ of pancreatic welldifferentiated neuroendocrine tumors in another 
Table 2 Methylation of RASSF1A, p14, p16 and MGMT genes in pancreatic, nonileal and ileal neuroendocrine tumors and clinicopathologic associations

\begin{tabular}{|c|c|c|c|c|c|c|c|c|}
\hline \multirow{2}{*}{$\begin{array}{l}\text { Clinicopathologic } \\
\text { features }\end{array}$} & \multicolumn{2}{|c|}{ RASSF1A gene \% (no.) } & \multicolumn{2}{|c|}{ p14 gene \% (no.) } & \multicolumn{2}{|c|}{ p16 gene \% (nо.) } & \multicolumn{2}{|c|}{ MGMT gene \% (no.) } \\
\hline & $\begin{array}{l}\text { Methylated } \\
(\mathrm{n}=27)\end{array}$ & $\begin{array}{l}\text { Unmethylated } \\
\quad(\mathrm{n}=20)\end{array}$ & $\begin{array}{l}\text { Methylated } \\
(\mathrm{n}=23)\end{array}$ & $\begin{array}{l}\text { Unmethylated } \\
\quad(\mathrm{n}=24)\end{array}$ & $\begin{array}{l}\text { Methylated } \\
(\mathrm{n}=12)\end{array}$ & $\begin{array}{l}\text { Unmethylated } \\
\quad(\mathrm{n}=35)\end{array}$ & $\begin{array}{l}\text { Methylated } \\
\quad(\mathrm{n}=6)\end{array}$ & $\begin{array}{l}\text { Unmethylated } \\
(\mathrm{n}=41)\end{array}$ \\
\hline Age (mean \pm s.d.) years & $60.0 \pm 12.1$ & $54.4 \pm 14.2$ & $58.9 \pm 12.0$ & $57.6 \pm 14.8$ & $68.3 \pm 8.7^{\mathrm{a}}$ & $54.8 \pm 13.0^{\mathrm{a}}$ & $59.0 \pm 10.9$ & $58.1 \pm 13.8$ \\
\hline \multicolumn{9}{|l|}{ Gender } \\
\hline Female & $41(11)$ & $65(13)$ & $52(12)$ & $50(12)$ & $42(5)$ & $54(19)$ & $50(3)$ & $51(21)$ \\
\hline Male & $59(16)$ & $35(7)$ & $48(11)$ & $50(12)$ & $58(7)$ & $46(16)$ & $50(3)$ & $49(20)$ \\
\hline $\begin{array}{l}\text { Size of tumor } \\
\text { (mean } \pm \text { s.d.) }(\mathrm{cm})\end{array}$ & $3.1 \pm 2.5$ & $3.3 \pm 5.1$ & $3.6 \pm 4.7$ & $3.3 \pm 2.4$ & $3.2 \pm 2.3$ & $3.6 \pm 4.1$ & $4.7 \pm 2.7$ & $3.3 \pm 3.8$ \\
\hline \multicolumn{9}{|l|}{ Histpathological type } \\
\hline WDNTB & $0(0)^{\mathrm{b}}$ & $15(3)^{\mathrm{b}}$ & $9(2)$ & $4(1)$ & $8(1)$ & $17(2)$ & $0(0)$ & $7(3)$ \\
\hline WTNTUMP & $15(4)^{b}$ & $25(5)^{\mathrm{b}}$ & $13(3)$ & $25(6)$ & 8 (1) & $23(8)$ & $33(2)$ & $17(7)$ \\
\hline WDNC & $85(23)^{\mathrm{b}}$ & $60(12)^{\mathrm{b}}$ & $78(18)$ & $71(17)$ & $83(10)$ & $71(25)$ & $67(4)$ & $76(31)$ \\
\hline \multicolumn{9}{|l|}{$\begin{array}{l}\text { Lymph node } \\
\text { metastasis }\end{array}$} \\
\hline Present & $78(21)^{\mathrm{c}}$ & $35(7)^{\mathrm{c}}$ & $52(12)$ & $67(16)$ & $75(9)$ & $54(19)$ & $50(3)$ & $61(25)$ \\
\hline Absent & $22(6)^{\mathrm{c}}$ & $65(13)^{\mathrm{c}}$ & 48 (11) & $33(8)$ & $25(3)$ & $46(16)$ & $50(3)$ & $39(16)$ \\
\hline \multicolumn{9}{|l|}{ Liver metastasis } \\
\hline Present & $41(11)$ & $40(8)$ & $43(10)$ & $38(9)$ & $67(8)^{\mathrm{d}}$ & $31(11)^{\mathrm{d}}$ & $7(1)$ & $44(18)$ \\
\hline Absent & $59(16)$ & $60(12)$ & $57(13)$ & $62(15)$ & $33(4)^{\mathrm{d}}$ & $69(24)^{\mathrm{d}}$ & $83(5)$ & $56(23)$ \\
\hline \multicolumn{9}{|l|}{ Vital status } \\
\hline Alive & $89(24)$ & $95(19)$ & $96(22)$ & $87(21)$ & $83(10)$ & $94(33)$ & $100(6)$ & $90(37)$ \\
\hline Dead & $11(3)$ & $5(1)$ & $4(1)$ & $13(3)$ & $17(2)$ & $6(2)$ & $0(0)$ & $10(4)$ \\
\hline
\end{tabular}

WDNC, well-differentiated neuroendocrine carcinoma; WDNTB, well-differentiated neuroendocrine tumor, benign; WDNTUMP, well-differentiated neuroendocrine tumor, uncertain malignant potential.

${ }^{\mathrm{a}} P=0.002$. The mean age of patients with ileal neuroendocrine tumors methylated at $p 16$ gene was $68.0 \pm 2.9$ years $v s 53.3 \pm 4.6$ years for unmethylated tumors $(P=0.03)$.

${ }^{\mathrm{b}} P=0.03$.

${ }^{\mathrm{C}} P=0.004$. Lymph node metastasis was present in $70 \%$ (7/10) of pancreatic neuroendocrine tumors methylated at $R A S S F 1 A$ gene $v s 0 \%(0 / 6)$ of unmethylated tumors $(P=0.002)$, and in $83 \%$ (5/6) of nonileal neuroendocrine tumors methylated at $R A S S F 1 A$ gene vs $22 \%(2 / 9)$ of unmethylated tumors $(P=0.049)$.

${ }^{\mathrm{d}} P=0.04$. Liver metastasis was present in $60 \%(3 / 5)$ of nonileal neuroendocrine tumors methylated at $p 16$ gene vs $10 \%(1 / 10)$ of unmethylated tumors $(P=0.04)$. 
Table 3 Number of methylated genes in pancreatic, nonileal and ileal neuroendocrine tumors and clinicopathologic associations

\begin{tabular}{|c|c|c|c|c|}
\hline \multirow[t]{2}{*}{ Clinicopathologic features } & \multicolumn{3}{|c|}{ Methylated genes \% (no.) } & \multirow[t]{2}{*}{$\mathrm{P}$-value } \\
\hline & None $(\mathrm{n}=8)$ & One $(\mathrm{n}=14)$ & Two or more $(\mathrm{n}=25)$ & \\
\hline Age (mean \pm s.d.) (years) & $45.7 \pm 14.9$ & $60.6 \pm 10.7$ & $61.4 \pm 12.7$ & $0.01^{\mathrm{a}}$ \\
\hline \multicolumn{5}{|l|}{ Gender } \\
\hline Female & $63(5)$ & $57(8)$ & $36(9)$ & \multirow[t]{2}{*}{ NS } \\
\hline Male & $37(3)$ & $43(6)$ & $64(16)$ & \\
\hline Size of primary tumor (mean \pm s.d.) $(\mathrm{cm})$ & $2.0 \pm 1.7$ & $4.4 \pm 6.2$ & $2.9 \pm 2.0$ & NS \\
\hline \multicolumn{5}{|l|}{ Histopathological type } \\
\hline WDNTB & $13(1)$ & $7(1)$ & $4(1)$ & \multirow[t]{3}{*}{ NS } \\
\hline WDNTUMP & $25(2)$ & $29(4)$ & $12(3)$ & \\
\hline WDNC & $62(5)$ & $64(9)$ & $84(21)$ & \\
\hline \multicolumn{5}{|l|}{ Lymph node metastasis } \\
\hline Present & $50(4)$ & $50(7)$ & $68(17)$ & \multirow[t]{2}{*}{ NS } \\
\hline Absent & $50(4)$ & $50(7)$ & $32(8)$ & \\
\hline \multicolumn{5}{|l|}{ Liver metastasis } \\
\hline Present & $50(4)$ & $14(2)$ & $52(13)$ & \multirow[t]{2}{*}{0.044} \\
\hline Absent & $50(4)$ & $86(12)$ & $48(12)$ & \\
\hline \multicolumn{5}{|l|}{ Vital status } \\
\hline Alive & $100(100)$ & $86(12)$ & $92(14)$ & \multirow[t]{2}{*}{ NS } \\
\hline Dead & $0(0)$ & $14(2)$ & $8(2)$ & \\
\hline
\end{tabular}

WDNC, well-differentiated neuroendocrine carcinoma; WDNTB, well-differentiated neuroendocrine tumor, benign; WDNTUMP, welldifferentiated neuroendocrine tumor, uncertain malignant potential.

${ }^{\mathrm{a}}$ The mean age of patients with pancreatic neuroendocrine tumors methylated in two or more genes was $59.6 \pm 3.2$ years compared to $60.7 \pm 5.7$ years for tumors methylated in one gene and $27.5 \pm 8.5$ years for tumors unmethylated in all four genes $(P=0.01)$.

study. ${ }^{7}$ In contrast, $p 16$ methylation was infrequent in pulmonary neuroendocrine tumors. ${ }^{22}$

p14 methylation was most prevalent in gastrointestinal tumors compared to other types of human tumors. ${ }^{26}$ In our study, we found frequent methylation of $p 14$ in well-differentiated neuroendocrine tumors. In contrast, we and others had previously reported a low frequency of $p 14$ methylation in pancreatic well-differentiated neuroendocrine tumors. ${ }^{6,7}$

In our study, MGMT methylation was not present in ileal well-differentiated neuroendocrine tumors and was infrequent in pancreatic and nonileal welldifferentiated neuroendocrine tumors. We have previously shown that complete loss of chromosome 18 is frequently present in ileal well-differentiated neuroendocrine tumors but not in nonileal or pancreatic well-differentiated neuroendocrine tumors. ${ }^{11}$ These findings suggest that ileal well-differentiated neuroendocrine tumors have differences in genetic and epigenetic alterations compared to well-differentiated neuroendocrine tumors from other sites. The MGMT gene is responsible for removing alkylation of DNA at the $O^{6}$ position of guanine. Methylation of $\mathrm{CpG}$ islands in the promoter region of MGMT can cause gene silencing. ${ }^{20}$ Frequent MGMT methylation is reported in brain tumors, colorectal cancers, lung cancers, head and neck cancers and high-grade lymphomas but is uncommon in pancreatic, renal, bladder, endometrial and breast carcinoma. $^{20}$

CpG island methylator phenotype has been reported in cancers from a variety of sites and types including colon, stomach and pancreas. ${ }^{35-37}$ In our study, methylation of $p 16$ gene and methylation of two or more genes were associated with liver metastasis, and methylation of $R A S S F 1 A$ gene with histopathologic type of tumor and lymph node metastasis. In another study, similar associations were reported between methylation of $p 16$ gene and lymph node metastasis, and between methylation of multiple genes and lymph node or liver metastasis in patients with pancreatic neuroendocrine tumors. ${ }^{7}$

In our study, $p 16$ gene methylation was more common in tumors from older patients. Age-related increase in methylation has been reported in normal tissue and cancer. ${ }^{38-40}$ In our study, RASSF1A gene methylation was present in four samples of nonneoplastic pancreatic parenchyma. However, in our study islets of Langherhans were a minor component in the samples of non-neoplastic pancreatic parenchyma, and it is possible that $R A S S F 1 A$ gene methylation may be present in the exocrine cells. Similarly, a previous study has reported RASSF1A gene methylation of non-neoplastic parenchyma. ${ }^{23}$ 
Age-related methylation of $R A S S F 1 A$ gene has been reported in a variety of tissues including pancreas ${ }^{41}$ but no association was present between age and RASSF1A gene methylation of non-neoplastic or tumor samples in our study.

In summary, our study shows that methylation profiles differ by tumor subsite, patient age and metastatic status. The findings in our study further support the concept that these three groups of tumor are fundamentally different and the tumorigenic process evolves along different pathways.

\section{Acknowledgements}

This study was supported by a grant to AR and JCY from Dr and Mrs Raymond R and Beverly Sackler and by Cancer Center Support Grant P30 CA16672 from the National Cancer Institute, National Institute of Health, Department of Health and Human Services.

\section{References}

1 Godwin II JD. Carcinoid tumors. An analysis of 2837 cases. Cancer 1975;36:560-569.

2 Leotlela PD, Jauch A, Holtgreve-Grez H, et al. Genetics of neuroendocrine and carcinoid tumours. Endocr Relat Cancer 2003;10:437-450.

3 Maggard MA, O’Connell JB, Ko CY. Updated population-based review of carcinoid tumors. Ann Surg 2004;240:117-122.

4 Modlin IM, Lye KD, Kidd M. A 5-decade analysis of 13715 carcinoid tumors. Cancer 2003;97:934-959.

5 Bartsch DK, Kersting M, Wild A, et al. Low frequency of p16(INK4a) alterations in insulinomas. Digestion 2000;62:171-177.

6 Chan AO, Kim SG, Bedeir A, et al. CpG island methylation in carcinoid and pancreatic endocrine tumors. Oncogene 2003;22:924-934.

7 House MG, Herman JG, Guo MZ, et al. Aberrant hypermethylation of tumor suppressor genes in pancreatic endocrine neoplasms. Ann Surg 2003;238: 423-431.

8 Lubomierski N, Kersting M, Bert T, et al. Tumor suppressor genes in the 9p21 gene cluster are selective targets of inactivation in neuroendocrine gastroenteropancreatic tumors. Cancer Res 2001;61:5905-5910.

9 Serrano J, Goebel SU, Peghini PL, et al. Alterations in the p16INK4a/CDKN2A tumor suppressor gene in gastrinomas. J Clin Endocrinol Metab 2000;85:41464156.

10 Rigaud G, Missiaglia E, Moore PS, et al. High resolution allelotype of nonfunctional pancreatic endocrine tumors: identification of two molecular subgroups with clinical implications. Cancer Res 2001; 61:285-292.

11 Wang GG, Yao JC, Worah S, et al. Comparison of genetic alterations in neuroendocrine tumors: frequent loss of chromosome 18 in ileal carcinoid tumors. Mod Pathol 2005;18:1079-1087.

12 Quelle DE, Zindy F, Ashmun RA, et al. Alternative reading frames of the INK4a tumor suppressor gene encode two unrelated proteins capable of inducing cell cycle arrest. Cell 1995;83:993-1000.

13 Serrano M, Lee $\mathrm{H}$, Chin L, et al. Role of the INK4a locus in tumor suppression and cell mortality. Cell 1996;85:27-37.

14 Serrano M, Hannon GJ, Beach D. A new regulatory motif in cell-cycle control causing specific inhibition of cyclin D/CDK4. Nature 1993;366:704-707.

15 Sherr CJ. Cancer cell cycles. Science 1996;274: 1672-1677.

16 Haber DA. Splicing into senescence: the curious case of p16 and p19ARF. Cell 1997;91:555-558.

$17 \mathrm{Kamb}$ A. Cell-cycle regulators and cancer. Trends Genet 1995;11:136-140.

18 Merlo A, Herman JG, Mao L, et al. 5' CpG island methylation is associated with transcriptional silencing of the tumour suppressor p16/CDKN2/MTS1 in human cancers. Nat Med 1995;1:686-692.

19 Esteller M, Corn PG, Baylin SB, et al. A gene hypermethylation profile of human cancer. Cancer Res 2001;61:3225-3229.

20 Esteller M, Hamilton SR, Burger PC, et al. Inactivation of the DNA repair gene $\mathrm{O}^{6}$-methylguanine-DNA methyltransferase by promoter hypermethylation is a common event in primary human neoplasia. Cancer Res 1999;59:793-797.

21 Agathanggelou A, Cooper WN, Latif F. Role of the RASassociation domain family 1 tumor suppressor gene in human cancers. Cancer Res 2005;65:3497-3508.

22 Toyooka S, Toyooka KO, Maruyama R, et al. DNA methylation profiles of lung tumors. Mol Cancer Ther 2001;1:61-67.

23 Dammann R, Schagdarsurengin U, Liu L, et al. Frequent RASSF1A promoter hypermethylation and K-ras mutations in pancreatic carcinoma. Oncogene 2003;22:3806-3812.

24 Rumilla KM, Zhang H, Erickson LA, et al. RASSF1A expression and gene methylation in ileal carcinoid tumors. Mod Pathol 2005;18:117A (abstract).

25 Klöppel G, Perren A, Heitz PU. The gastroenteropancreatic neuroendocrine cell system and its tumors: the WHO classification. Ann NY Acad Sci 2004;1014: 13-27.

26 Esteller M, Tortola S, Toyota M, et al. Hypermethylation-associated inactivation of $\mathrm{p} 14(\mathrm{ARF})$ is independent of p16(INK4a) methylation and p53 mutational status. Cancer Res 2000;60:129-133.

27 Herman JG, Merlo A, Mao L, et al. Inactivation of the CDKN2/p16/MTS1 gene is frequently associated with aberrant DNA methylation in all common human cancers. Cancer Res 1995;55:4525-4530.

28 Lo KW, Kwong J, Hui AB, et al. High frequency of promoter hypermethylation of $R A S S F 1 A$ in nasopharngeal carcinoma. Cancer Res 2001;61:38773881.

29 Dammann R, Li C, Yoon JH, et al. Epigenetic inactivation of a RAS association domain family protein from the lung tumour suppressor locus 3p21.3. Nat Genet 2000;25:315-319.

30 Burbee DG, Forgacs E, Zochbauer-Muller S, et al. Epigenetic inactivation of RASSF1A in lung and breast cancers and malignant phenotype suppression. J Natl Cancer Inst 2001;93:691-699.

31 Lerman MI, Minna JD. The 630-kb lung cancer homozygous deletion region on human chromosome 3p21.3: identification and evaluation of the resident candidate tumor suppressor genes. The International 
Lung Cancer Chromosome 3p21.3 Tumor Suppressor Gene Consortium. Cancer Res 2000;60:6116-6133.

32 Rindi G, Candusso ME, Solcia E. Molecular aspects of the endocrine tumours of the pancreas and the gastrointestinal tract. Ital J Gastroenterol Hepatol 1999;31:S135-S138.

33 Weber HC, Jensen RT. Pancreatic endocrine tumores and carcinoid tumors: recent insights from genetic and molecular biologic studies. In: Dervenis CG (ed). Advances in Pancreatic disease: Molecular Biology, Diagnosis and Treatment. Georg Thieme Verlag: New York, NY, 1996, pp 55-75.

34 Muscarella P, Melvin WS, Fisher WE, et al. Genetic alterations in gastrinomas and nonfunctioning pancreatic neuroendocrine tumors: an analysis of p16/ MTS1 tumor suppressor gene inactivation. Cancer Res 1998;58:237-240.

35 Toyota M, Ahuja N, Ohe-Toyota M, et al. CpG island methylator phenotype in colorectal cancer. Proc Natl Acad Sci USA 1999;96:8681-8686.
36 Toyota M, Ahuja N, Suzuki $\mathrm{H}$, et al. Aberrant methylation in gastric cancer associated with the CpG island methylator phenotype. Cancer Res 1999; 59:5438-5442.

37 Ueki T, Toyota M, Sohn T, et al. Hypermethylation of multiple genes in pancreatic adenocarcinoma. Cancer Res 2000;60:1835-1839.

38 Ahuja N, Li Q, Mohan AL, et al. Aging and DNA methylation in colorectal mucosa and cancer. Cancer Res 1998;58:5489-5494.

39 Ahuja N, Issa JP. Aging, methylation and cancer. Histol Histopathol 2000;15:835-842.

40 Toyota M, Issa JP. CpG island methylator phenotypes in aging and cancer. Semin Cancer Biol 1999; 9:349-357.

41 Waki T, Tamura G, Sato M, et al. Age-related methylation of tumor suppressor and tumor-related genes: an analysis of autopsy samples. Oncogene 2003;22: 4128-4133. 